\title{
Does Darwin's naturalization hypothesis explain fish invasions?
}

\author{
Anthony Ricciardi* \& Miriam Mottiar \\ Redpath Museum, McGill University, Montreal, Quebec, H3A 2K6, Canada ; *Author for correspondence \\ (e-mail: tony.ricciardi@mcgill.ca; fax: +1-514-398-3185)
}

Received 11 April 2005; accepted in revised form 18 January 2006

Key words: biotic resistance, colonization, exotic species, invasion success, nonindigenous species, prediction

\begin{abstract}
Darwin's naturalization hypothesis predicts that introduced species tend not to invade areas containing congeneric native species, because they would otherwise compete with their close relatives and would likely encounter predators and pathogens that can attack them. An opposing view is that introduced species should succeed in areas where native congeners are present because they are more likely to share traits that pre-adapt them to their new environment. A test of both these hypotheses using data on fish introductions from several independent regions fails to support either viewpoints. In contrast to studies of nonindigenous plants, our results suggest that taxonomic affiliation is not an important general predictor of fish invasion success.
\end{abstract}

\section{Introduction}

Recent attempts at developing generalizations for invasion ecology have focused on predicting the successful establishment of introduced species (Kolar and Lodge 2001, 2002; Marchetti et al. 2004). Most introduced species fail to establish; establishment success varies across taxa (Williamson and Fitter 1996; Lockwood 1999) and across regions (Ross 1991). Numerous factors have been proposed to explain this variation, including propagule pressure, reproductive capacity, broad environmental tolerances, prior disturbance in the recipient community, and release from natural biotic constraints (Kolar and Lodge 2001; Colautti et al. 2004; Levine et al. 2004; Lockwood et al. 2005). Owing to this broad array of factors, some of which are extremely difficult to measure directly, proxy variables have been sought to predict invasion success; such variables include the size of a species' native range and its invasion history (Rejmanek 1996, 1998; Ricciardi and Rasmussen 1998). Most characteristics that have been quantitatively tested have been examined for plant or bird species (Kolar and Lodge 2001). These studies reveal very few characteristics or proxy variables that consistently predict invasion success. Furthermore, few studies have examined invasion success as a function of the relationship between the introduced species and members of the recipient assemblage, despite that the outcome of a species introduction is context-dependent (Moyle and Light 1996; Rejmanek 1998; Harvey et al. 2004).

In a hypothesis that has been only sparingly tested to date, Darwin (1859) proposed that introduced plants are less likely to invade (i.e. become 'naturalized' in) areas with congeneric native species because the introduced species would compete with the closely-related natives 
and, furthermore, they would encounter native herbivores and pathogens that could use them as hosts. In the third chapter of Origins of Species, Darwin made the following assertion:

"As species of the same genus have usually, though by no means invariably, some similarity in habits and constitution, and always in structure, the struggle will be more severe between species of the same genus, when they come into contact with each other, than between species of distinct genera."

And in Chapter 4, he proposes what has become known as Darwin's naturalization hypothesis:

"It might have been expected that the plants which have succeeded in becoming naturalized in any land would generally have been closely allied to the indigenes; for these are commonly looked at as specially created and adapted for their own country. It might, also, perhaps have been expected that naturalized plants would have belonged to a few groups more especially adapted to certain stations in their own homes. But the case is very different... Floras gain by naturalization, proportionally with the number of native genera and species, far more in new genera than in new species. ... We see thus that these naturalized plants are of a highly diversified nature. They differ, moreover, to a large extent from the indigenes..."

Note that in the above statement Darwin considers an alternative possibility, hereafter termed the 'pre-adaptation hypothesis': that successful invaders are more likely to belong to the same genera as species native to the recipient community, because they are more likely to contain traits that pre-adapt them to the new environment (e.g. its climate; Curnutt 2000). Thus, the question becomes whether biotic resistance to establishment (through negative interspecific interactions) is more important to invasion success than the invader's tolerance to local abiotic factors. Darwin's naturalization hypothesis has rarely been tested statistically and results thus far have been equivocal; some studies support Darwin's hypothesis (Rejmanek 1996, 1998), while others reject it and, in some cases, support the pre-adaptation hypothesis (Daehler 2001; Duncan and Williams 2002).
It would be useful to extend this analysis to animal introductions. There is no theoretical reason that Darwin's hypothesis should apply only to plant species, unless competitive interactions among plants are substantially more intense than for animals. Here we provide the first test of Darwin's naturalization hypothesis to animal assemblages.

\section{Methods}

We tested the hypothesis on fish assemblages because (1) fishes have been widely introduced outside of their historic ranges; (2) they are frequently studied and collected for commercial, recreational and scientific purposes; (3) species are easily identified; and (4) introduced species are often conspicuous. We searched the literature for regions with well-documented histories of fish introductions. Introduced nonindigenous fishes in each region were classified as either successful invaders (i.e. having established a reproducing population, as inferred from multiple discoveries of adult and juvenile life stages) or failed invaders. After classifying each invader, we determined if a native species in the same genus was present in the region. In most regions there were low numbers of shared genera, which can reduce statistical power; therefore, we retained only those regions or systems which had at least five shared genera and at least five failed invaders. Our final data set included 11 spatially-independent systems and subcontinental regions. Data for most regions were obtained from FishBase (Froese and Pauly 2004) and from the FAO Database on Introductions of Aquatic Species (http://www.fao.org/ waicent/faoinfo/fishery/statist/fisoft/dias/mainpage. htm).

To determine if successful invaders are more likely than failed invaders to belong to unshared genera, a one-tailed Fisher Exact Test was used to examine the independence of row and column data in a $2 \times 2$ contingency table for each region. A meta-analysis of all regions was then conducted using Fisher's method of combining probabilities from independent tests of significance (Sokal and Rohlf 1995). Fisher's method adds the logarithms of $P$ values from each independent 
test to produce a single Chi-square statistic $\left(\chi^{2}\right)$ as follows:

$$
\chi^{2}=-2 \sum_{i} \ln P_{i}
$$

The $P$ value for this Chi-square statistic was computed with $2 n$ degrees of freedom, where $n$ is the total number of independent tests, for Darwin's hypothesis (right-tailed tests summarized in Table 1) and also for the pre-adaptation hypothesis (left-tailed tests in Table 1).

\section{Results}

For 8 of the 11 regions, the ratio of unshared to shared genera is greater for successful invaders than for failed invaders, consistent with Darwin's hypothesis. However, the left-tailed tests are significant for only one region, France $(P=0.029$; Table 1), although the $P$ values for the Baltic Sea and Poland fish assemblages are suggestively low $(P=0.131$ and 0.126 , respectively). One righttailed test is significant, that being for Chesapeake Bay $(P=0.044)$. No test remains significant at the 0.05 level after Bonferroni correction. When the probabilities are combined, there is no support for either Darwin's hypothesis (Fisher's Combined Probability test; $\chi^{2}=24.90$, $\mathrm{df}=22,0.25<P<0.5$ ) or for the pre-adaptation hypothesis $\left(\chi^{2}=11.51, \mathrm{df}=22, P>0.95\right)$. A similar result is obtained if we examine only the four regions defined by natural hydrological boundaries $(P>0.25$ for both hypotheses).

\section{Discussion}

There are two general views concerning what governs invasion success. The first espouses the classical idea that success is determined primarily by the outcome of competitive interactions (e.g., Case 1990). The second argues that success is determined by propagule pressure and abiotic environmental factors, particularly the degree to which the introduced species' physiological tolerances are compatible with local physical conditions (e.g., Moyle and Light 1996; MacIsaac et al. 2001). The first view is the basis for biotic resistance theory, which includes Darwin's hypothesis (Rejmanek 1996, 1998; Levine et al. 2004). It has been revitalized by recent research activity on the effect of enemy release on invasion success, which has yielded equivocal results (see Colautti et al. 2004 for review). If enemy release is important for the establishment of an introduced species, then introduced species similar to resident native species should be prone to failure because they are likely to encounter predators and parasites that are adapted to them.

Table 1. Numbers of introduced fish species belonging to genera shared and unshared by native species.

\begin{tabular}{|c|c|c|c|c|c|c|c|}
\hline \multirow[t]{2}{*}{ Region } & \multicolumn{2}{|c|}{ Successful invaders } & \multicolumn{2}{|l|}{ Failed invaders } & \multicolumn{2}{|l|}{$P$ value } & \multirow[t]{2}{*}{ Sources } \\
\hline & Shared genera & Unshared genera & Shared genera & Unshared genera & Left-tailed & Right-tailed & \\
\hline Laurentian Great Lakes & 3 & 18 & 6 & 13 & 0.177 & 0.955 & $1,2,3$ \\
\hline Hudson River & 7 & 24 & 0 & 5 & 1.000 & 0.315 & 4 \\
\hline Chesapeake Bay & 10 & 19 & 1 & 14 & 0.995 & 0.044 & 5 \\
\hline Baltic Sea & 0 & 6 & 7 & 14 & 0.131 & 1.000 & 6 \\
\hline Czech Republic & 4 & 15 & 2 & 9 & 0.739 & 0.620 & 7,8 \\
\hline France & 4 & 26 & 5 & 5 & 0.029 & 0.997 & 7,8 \\
\hline Germany & 6 & 12 & 3 & 4 & 0.499 & 0.819 & 7,8 \\
\hline Italy & 13 & 28 & 2 & 4 & 0.634 & 0.717 & 7,8 \\
\hline Japan & 5 & 22 & 3 & 11 & 0.565 & 0.743 & 7,8 \\
\hline Mexico & 9 & 19 & 3 & 3 & 0.351 & 0.901 & 7,8 \\
\hline Poland & 2 & 15 & 3 & 4 & 0.126 & 0.986 & 7,8 \\
\hline
\end{tabular}

One-tailed $P$ values from Fisher Exact tests are shown. Significant left-tailed tests support Darwin's hypothesis that successful invaders tend to be distinct from native species (i.e. belong to unshared genera). Significant right-tailed tests support the pre-adaptation hypothesis that successful invaders tend to be closely-related (share genera) with native species.

Sources: (1) Cudmore-Vokey and Crossman 2000; (2) Kolar and Lodge 2002; (3) Leach 2003; (4) Mills et al. 1997; (5) Fofonoff et al. 2003; (6) Leppäkoski and Olenin 2000; (7) Froese and Pauly 2004; (8) FAO Database on Introductions of Aquatic Species. 
The importance of biotic resistance in governing fish invasions, and freshwater invasions in general, has scarcely been studied (Baltz and Moyle 1993; Shurin 2000; Harvey et al. 2004). However, our study finds no evidence supporting Darwin's hypothesis, which is consistent with Moyle and Light's (1996) proposition that biotic resistance plays only a minor role in fish invasions and, therefore, given sufficient opportunity and appropriate abiotic conditions, introduced species will invade regardless of the biota already present.

\section{Potential sources of error}

The proportion of successful invasions recorded in each system was remarkably high $(22-87 \%$, median $71 \%$ ) compared with other taxa (Williamson and Fitter 1996). Our study likely underestimated numbers of failed invasions, presuming that some of these have gone undocumented. By contrast, previous studies (Rejmanek 1996, 1998; Daehler 2001) that assumed equal invasion opportunity for all species from a given donor pool have certainly overestimated the number of failed invaders, an error we avoided by considering only species known to have been introduced to the target region. However, given that most invasions require multiple introductions to succeed (Lockwood et al. 2005), some transient species (recorded as failed invaders) may not have arrived in sufficient numbers to establish a reproducing population. Conversely, human preferences for certain species (e.g. game fishes and ornamental fishes; Duggan et al. 2006) has undoubtedly resulted in disproportionate opportunities for particular taxonomic groups to become established ( $c f$. Lockwood 1999), obscuring any effects of biotic resistance.

Our dataset included large regions in which some native species were not sympatric with introduced congeners and thus had no opportunity to competitively exclude them. Furthermore, a number of native species that were historically present are no longer extant, or are so rare as to be ecologically extinct in a given region.

Finally, taxonomic similarity might not be well correlated with ecological similarity among fishes, which could explain why we found no support for the pre-adaptation hypothesis. Alternatively, if the mismatch of a single physiological parameter can prevent the establishment of a species, variation in the physiological tolerances within a genus might be great enough to supersede the importance of any ecological similarities between congeners. In any case, our results suggest that taxonomic affiliation is not an important predictor of fish invasions.

\section{Acknowledgements}

Funding from the Natural Sciences and Engineering Research Council of Canada is gratefully acknowledged.

\section{References}

Baltz DM and Moyle PB (1993) Invasion resistance to introduced species by a native assemblage of Californian stream fishes. Ecological Applications 3: 246-255

Case TJ (1990) Invasion resistance arises in strongly interacting species-rich model competition communities. Proceedings of the National Academy of Sciences of the United States of America 87: 9610-9614

Colautti RI, Ricciardi A, Grigorovich IA and MacIsaac HJ (2004) Is invasion success explained by the Enemy Release Hypothesis? Ecology Letters 7: 721-733

Cudmore-Vokey B and Crossman EJ (2000) Checklists of the fish fauna of the Laurentian Great Lakes and their connecting channels. Canadian Manuscript Report of Fisheries and Aquatic Sciences, No. 2550

Curnutt JL (2000) Host-area climatic-matching: similarity breeds exotics. Biological Conservation 94: 341-351

Daehler CC (2001) Darwin's naturalization hypothesis revisited. American Naturalist 158: 324-330

Darwin C (1859) On the Origin of Species by Means of Natural Selection. John Murray, London

Duggan IC, Rixon AM and MacIsaac HJ (2006) Popularity and propagule pressure: determinants of introduction and establishment of aquarium fish. Biological Invasions 8:377-382

Duncan RP and Williams PA (2002) Darwin's naturalization hypothesis challenged. Nature 417: 608

Fofonoff PW, Ruiz GM, Steves B, Hines AH and Carlton JT (2003) National Exotic Marine and Estuarine Species Information System. http://invasions/si.edu/nemesis/

Froese R and Pauly D (2004) FishBase. World Wide Web electronic publication. www.fishbase.org, version (10/2004)

Harvey BC, White JL and Nakamoto RJ (2004) An emergent multiple predator effect may enhance biotic resistance in a stream assemblage. Ecology 85: 127-133

Kolar CS and Lodge DM (2001) Progress in invasion biology: predicting invaders. Trends in Ecology and Evolution 16: 199-204 
Kolar CS and Lodge DM (2002) Ecological predictions and risk assessments for alien fishes in North America. Science 298: 1233-1236

Leach JH (2003) Unusual invaders of Lake Erie. Point Pelee Natural History News 3(1), 1-5

Leppäkoski E and Olenin S (2000) Non-native species and rates of spread: lessons from the brackish Baltic Sea. Biological Invasions 2: 151-163

Levine JM, Adler PB and Yelenik SG (2004) A meta-analysis of biotic resistance to exotic plant invasions. Ecology Letters 7: 975-989

Lockwood JL (1999) Using taxonomy to predict success among introduced avifauna: relative importance of transport and establishment. Conservation Biology 13: 565-567

Lockwood JL, Cassey P and Blackburn T (2005) The role of propagule pressure in explaining species invasions. Trends in Ecology and Evolution 20: 223-228

MacIsaac HJ, Grigorovich IA and Ricciardi A (2001) Reassessment of species invasions concepts: the Great Lakes basin as a model. Biological Invasions 3: 405-416

Marchetti MP, Moyle PB and Levine R (2004) Alien fishes in California watershed: characteristics of successful and failed invaders. Ecological Applications 14: 587-596

Mills EL, Scheuerell MD, Carlton J and Strayer DL (1997) Biological invasions in the Hudson River basin: an inventory and historical analysis. New York State Museum Circular No. 57, New York State Education Department, Albany

Moyle PB and Light T (1996) Fish invasions in California: do abiotic factors determine success. Ecology 77: 1666-1670

Rejmanek M (1996) A theory of seed plant invasiveness: the first sketch. Biological Conservation 78: 171-180

Rejmanek M (1998) Invasive plant species and invadible ecosystems. In: Sandlund OT, Schei PJ and Vilken A (eds) Invasive Species and Biodiversity Management, pp 79-102. Kluwer, Dordrecht

Ricciardi A and Rasmussen JB (1998) Predicting the identity and impact of future biological invaders: a priority for aquatic resource management. Canadian Journal of Fisheries and Aquatic Sciences 55: 1759-1765

Ross ST (1991) Mechanisms structuring stream fish assemblages: are there lessons from introduced species. Environmental Biology of Fishes 30: 359-368

Shurin JB (2000) Dispersal limitation, invasion resistance, and the structure of pond zooplankton communities. Ecology 81: 3074-3086

Sokal RR and Rohlf FJ (1995) Biometry, 3rd edition. Freeman, New York

Williamson MH and Fitter A (1996) The varying success of invaders. Ecology 77: 1661-1666 